\title{
THE RIGHT TO JURY TRIAL IN COMPLEX CIVIL LITIGATION
}

\begin{abstract}
This Comment examines the growing trend to strike jury demands in complex commercial litigation. The first section reviews the historical background of the seventh amendment right to jury trial. The second section examines Ross v. Bernhard, the leading Supreme Court precedent on the right. The writer next explores the five recent lower court cases dealing with a motion to strike jury demand. Finally, the writer critically evaluates the new trend and demonstrates that Ross has been misinterpreted.
\end{abstract}

\section{INTRODUCTION}

In almost all criminal and civil trials, United States law strongly favors trial by jury. 1 The seventh amendment to the United States Constitution embodies this preference with respect to civil actions; the amendment guarantees the right to jury trial in all suits not of an equitable or admiralty jurisdiction. ${ }^{2}$ In the last three years, five cases wrestled with the problem of a jury's ability to competently decide a complicated suit. ${ }^{3}$ Four of the cases held that in extremely complex cases, juries are incompetent triers of fact and on that ground overrode the seventh amendment. ${ }^{4}$ However, one case disapproved this trend and stated that the fun-

1. Simler v. Conner, 372 U.S. 221, 222 (1963); Dimick v. Schiedt, 293 U.S. 474, 485-86 (1935).

2. The seventh amendment provides: "In Suits at common law, where the value in controversy shall exceed twenty dollars, the right of trial by jury shall be preserved, and no fact tried by jury, shall be otherwise re-examined in any Court of the United States, than according to the rules of the common law." U.S. ConST. amend. VII.

3. ILC Peripherals Leasing Corp. v. International Business Mach. Corp., 458 F. Supp. 423 (N.D. Cal. 1978); Bernstein v. Universal Pictures, Inc., 79 F.R.D. 59 (S.D.N.Y. 1978); Radial Lip Mach., Inc. v. International Carbide Corp., 76 F.R.D. 224 (N.D. Ill. 1977); In, re United States Fin. Sec. Litigation, 75 F.R.D. 702 (S.D. Cal. 1977); In re Boise Cascade Sec. Litigation, 420 F. Supp. 99 (W.D. Wash. 1976).

4. ILC Peripherals Leasing Corp. v. International Business Mach. Corp., 458 F. Supp. 423 (N.D. Cal. 1978); Bernstein v. Universal Pictures, Inc., 79 F.R.D. 59 (S.D.N.Y. 1978); In re United States Fin. Sec. Litigation, 75 F.R.D. 702 (S.D. Cal. 1977); In re Boise Cascade Sec. Litigation, 420 F. Supp. 99 (W.D. Wash. 1976).

August 1979 Vol. 16 No. 5 
damental right to jury trial cannot be eroded by the complexity of the case. 5

The decision in each of these cases rested on Ross v. Bernhard, ${ }^{6}$ yet three different interpretations emerged. The Court in Ross attempted to formulate a three-pronged test to aid in determining whether an issue is legal or equitable in nature. Once the issue is labeled legal, the right to a jury trial attaches. ${ }^{7}$ The conflicting interpretations of Ross indicate that the test is not clearly understood by the courts.

\section{HISTORICAL BACKGROUND}

The prevailing view is that the institution of the jury is of continental origin and was introduced into England by the Norman Kings as early as the eleventh century. ${ }^{8}$ However, the English developed a bifurcated system consisting of the Common Law Court and the Court of Chancery. The procedure in Chancery differed materially from that in the Common Law Courts; in Chancery there was no right to a jury trial.9

Hardships and inconveniences occurred because of the bifurcated system of law and equity. Those suing in equity were often dismissed because their proper remedy was at law. Parties in actions at law could not raise equitable claims or defenses. Therefore, two suits were necessary to hear the equitable and legal claims arising from a single transaction. ${ }^{10}$

When creating the federal court system in 1789, Congress drew upon the English system and developed a single court system that administered law and equity separately.11 The procedures and rules in a court of equity were different from those in a court of law.12 Furthermore, the adoption of the seventh amendment in 1791 continued the English practice of expressly allowing jury trials only in suits at common law.13

5. Radial Lip Mach., Inc. v. International Carbide Corp., 76 F.R.D. 224 (N.D. III. 1977).

6. 396 U.S. 531 (1970).

7. See text accompanying notes 20-37 infra.

8. 5 MOORE'S FEDERAL PRACTICE \] 38.02, at 8.2-9 (2d ed. 1978).

9. E. Morgan, The Study of Law 9-13 (2d ed. 1948). See F. James \& G. HazARD, CIVIL PROCEDURE $\$ \S 1.3-.5$, at 8-16 (2d ed. 1977), for an in-depth discussion of the English development of the Court of Chancery.

10. F. James \& G. HAZARD, Crvil Procedure \$ 1.5, at 15-18 (2d ed. 1977).

11. Id. (citing C. CLARK, CODE PLEADING \& 9 (2d ed. 1947)).

12. 5 MOORE'S FEDERAI PRACTICE, ๆ 38.08, at 79-80 (2d ed. 1978).

13. See note 2 supra. Both Blackstone and Story spoke of the right to jury trial at common law in glowing terms. "Blackstone thought the jury to be the 'principal criterion of truth in the law of England' and the right to trial by jury to be the 'most transcendent privilege which any subject can enjoy or wish for.' 5 Moore's Federal Practice ๆ 38.02, at 9-10 (2d ed. 1978). See also C. Wright, LAw 
The courts generally have interpreted the seventh amendment as preserving the jury trial right that existed at common law in England in 1791.14 The amendment addresses only suits at com-

OF FEDERAL Courts §92, at 447 (3d ed. 1976). Moore also points out that in England today, the jury is "seldom employed in civil suits, has been abandoned in criminal prosecutions other than for major crimes, and even there is used decreasingly." 5 MoOre's Federal Practice I 38.02, at 10 (2d ed. 1978) (citing Judge Frank in Skidmore v. Baltimore \& Ohio R.R. Co., 167 F.2d 54, 56 n.4 (2d Cir. 1948)). See also F. Kirkham, Complex Civil Litigation-Have Good Intentions Gone Awry? (Apr. 1976) (address delivered at The Pound Conference), reprinted in 70 F.R.D. 199, 209 (1976).

Story states, "[The seventh amendment] is a most important and valuable amendment; and places upon the high ground of constitutional right the inestimable privilege of a trial by jury in civil cases . . . which is conceded by all to be essential to political and civil liberty." 5 MOORE'S FEDERAL PRACTICE fi 38.02, at 10 (2d ed. 1978) (citing 3 Story's Commentaries on the ConstTutTion 633 (1833)).

While Holdsworth recognized some defects in the jury, he listed the following virtues of the jury:

1. The litigant gets a body of persons who bring average common sense to bear upon the facts of his case. 2. The findings of the jury create no precedent; and thus the jury can decide hard cases equitably without making bad law. 3. Litigants are generally contented with the measure of justice meted out by a jury. 4. A jury helps to preserve the dignity of the bench by relieving the judge of the responsibility of deciding simply upon his own opinion. 5. The jury itself is educated by its participation in the administration of justice. 6. The jury makes the law intelligible by constantly bringing the rules of law to the touchstone of common sense.

W. HOLDSWORTH, A HISTORY OF ENGLiSH LAW 348-50 (6th ed. 1938), cited in 5 MOORE'S FEDERAI PRACTICE \38.02, at 11-12 (2d ed. 1978).

On the other hand, Hamilton felt the use of the jury should be subject to legislative discretion rather than to the rigid dictates of the Constitution. THE FEDERAL-

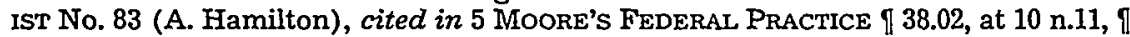
38.08 , at 69-71 (2d ed. 1978). A modern critic of the right to jury trial was the late Judge Frank. He believed that use of the jury is not justified in civil litigation. J. Frank, Courts on Trial 110-11 (1949), cited in 5 Moore's Federal. Practice If 38.02, at 12-14 (2d ed. 1978). Various criticisms are as follows: (1) The jury gives no reasons for its verdict; thus the verdict may reflect popular prejudice of the day. (2) The jury is capable of intimidation. (3) Use of juries causes delay. (4) Many jurors are incompetent triers of fact. See Redish, Seventh Amendment Right to Jury Trial: A Study in the Irrationality of Rational Decision Making, 70 Nw. U.L. REv. 486, 502-08 (1975), for a discussion of the pros and cons of the civil jury and a comprehensive listing of articles, books, and views on the subject. For the purposes of this Comment, suffice it to say that the desirability and validity of juries is an area open to great debate. However:

Despite the theoretical case against the jury and much buttressing reality,

the jury system has persisted in this country. Undoubtedly it will con-

tinue to do so for some time, because it fulfills a felt need. The jury is like

rock music. Classical theory frowns; the masses applaud. And in a de-

mocracy the felt need of the masses has a claim upon the law.

5 MOORE's FEDERAL PRACTICE If 38.02, at 15 (2d ed. 1978).

14. Baltimore \& Carolina Line, Inc. v. Redman, 295 U.S. 654, 657 (1935); Slocum v. New York Life Ins. Co., 228 U.S. 364, 377 (1913); Capital Traction Co. v. Hof, 174 U.S. 1, 22-23 (1899); Parsons v. Bedford, 28 U.S. (3 Pet.) 433, 446 (1830); United 
mon law. Therefore, the Supreme Court construed the amendment to have no application to equity suits.15 In ascertaining the scope of the seventh amendment, the Supreme Court applied the "historical test," which looked to the common law rules at the time the amendment was adopted in 1791.16

The use of the historical test became complicated by the merger of law and equity. In 1938, the federal courts achieved the procedural union of law and equity by adopting the Federal Rules of Civil Procedure.17 Merger allowed parties to claim both legal and equitable issues in one lawsuit.18 The determination of what the English practice was in 1791 was sufficiently difficult without the additional burden of adapting that practice to the newly merged procedures. ${ }^{19}$ As a result, the Supreme Court attempted

States v. Wonson, 28 F. Cas. 745, 750 (C.C.D. Mass. 1812) (No. 16,750); 5 MoonE's Federal Practice ff 38.08, at 79 (2d ed. 1978). The following is a list of the actions traditionally believed to be actions at common law as they existed prior to 1791: trespass to property and person, including assault, battery, and false imprisonment; trespass on the case, including negligence, patent, copyright, trademark infringement, literary piracy, violation of antitrust acts, nuisance, fraud and deceit, slander, libel, and malicious prosecution; trover to recover damages for conversion of personal property; detinue and replevin for wrongful detention of personal property; ejectment to recover possession of land; covenant to recover on a sealed instrument; debt; general assumpsit; and special assumpsit to recover damages on a simple contract. 5 MOORE's FEDERAL PRACTICE $\mid$ 38.11, at 118-20 (2d ed. 1978).

15. Yakus v. United States, 321 U.S. 414, 447 (1944); Shields v. Thomas, 59 U.S. (18 How.) 253, 262 (1855). However, this principle did not preclude the application of the seventh amendment to newly created rights of a legal nature, which would under common law principles be enforced in a suit at common law. 5 Moone's Federal Practice I 38.08, at 79-80 (2d ed. 1978). Nor does the amendment apply to suits in admiralty, Crowell v. Benson, 285 U.S. 22, 45 (1932), or to administrative proceedings, NLRB v. Jones \& Laughlin Steel Corp., 301 U.S. 1, $48-49$ (1937).

16. See Dimick v. Schiedt, 293 U.S. 474,476 (1935).

17. FED. R. CIV. P. 1, 2.

18. Rule 18 permits a party to join as many claims, "legal, equitable, or maritime," as he or she has against the defendant. FED. R. CIV. P. 18(a). Although the rule is permissive and failure to join a claim does not bar its assertion in another action, if the second claim is really a part of the first cause of action the rule against splitting a single cause of action will prohibit suit on the second claim. 3A MoORE'S Federal Practice ๆ 18.04, at 18-13 (2d ed. 1978).

19. [M] erger made the Seventh Amendment historical test extremely difficult to apply when, under the broad provisions of the Federal Rules for joinder of claims, equitable and legal remedies were sought alternatively or cumulatively; or when, under the Rules' provisions for compulsory and permissive counterclaims, legal counterclaims were made to equitable claims or equitable counterclaims to legal claims. In such situations, "issues formerly equitable are for the court; issues formerly legal are normally for the jury if timely demand is made." The sequence in which these issues are tried, however, has great importance. For if the equitable and legal issues arise out of the same transaction or occurrence, adjudicating the equitable issues first may operate through collateral estoppel to prevent a jury trial of the legal issues.

Note, Ross v. Bernhard: The Uncertain Future of the Seventh Amendment, 81 YALE L.J. 112, 114-15 (1971). See also FED. R. Crv. P. 13 (counterclaims) and 18(a) (joinder of claims). 
to unravel the problem areas on a case-by-case basis.

\section{Modern Supreme Court Treatment of the Seventh AMENDMENT RIGHT TO JURY TRIAL}

The United States Supreme Court expounded the modern view of the seventh amendment in the trilogy of Beacon Theatres, Inc. v. Westover, ${ }^{20}$ Dairy Queen, Inc. v. Wood, ${ }^{21}$ and Ross v. Bernhard.22 The Court rejected the notion that the application of the seventh amendment compels categorization of rights and remedies as legal or equitable on a rigidly historical basis. Procedural obstacles created before the merger of law and equity will not prevent a jury trial.23

Beacon Theatres, Inc. v. Westover ${ }^{24}$ is the seminal case limiting the purely historical approach in defining law and equity. The Supreme Court analyzed the problem of legal cross-claims and counterclaims brought against the original equity claimant. The case was an action for a declaration that certain contracts were reasonable and were in compliance with antitrust laws. The complaint also prayed for an injunction restraining the defendant from suing until the plaintiff's action could be determined. The defendant filed a counterclaim against the plaintiff and a crossclaim against an intervenor, charging a violation of the antitrust laws. The defendant demanded a jury trial.

Justice Black, writing for the Court, conceded that prior to merger, a court of equity could enjoin an action at law and dispose of the entire case before it. A contrary rule would deprive the equity plaintiff of an orderly disposition of the entire controversy. Thus, the Beacon Theatres situation would have been treated as a single controversy and the parties would be denied the right to a jury trial. However, Justice Black stated that the seventh amendment should not necessarily apply to actions under the Federal Rules in the same manner as the pre-merger

20. 359 U.S. 500 (1959).

21. 369 U.S. 469 (1962).

22. 396 U.S. 531 (1970).

23. See Note, Congressional Provisions for Nonjury Trials under the Seventh Amendment, 83 Y ALE L.J. 401 (1973); Comment, From Beacon Theatres to Dairy Queen to Ross: The Seventh Amendment, The Federal Rules, and a Receding LawEquity Dichotomy, 48 J. URB. L. 459 (1971). For an in-depth look at Beacon Theatres, see McCoid, Procedural Reform and the Right to Jury Trial: A Study of Beacon Theatres, Inc. v. Westover, 116 U. PA. L. REv. 1 (1967).

24. 359 U.S. 500 (1959). 
practice. Courts must reevaluate traditional equity rules in light of the liberal joinder provisions in the Federal Rules which allow legal and equitable causes to be brought and resolved in one civil suit.25 As a result, the Court in Beacon Theatres held that courts must separate the legal and equitable claims and conduct a jury trial on the legal issues first. As long as the action involves a legal claim, a party has the right to a jury trial on demand.

Dairy Queen, Inc. $v$. Wood 26 reinforced Beacon Theatres. The complaint sought an injunction against further use of a trade name, an accounting to determine the exact amount owed by a licensee, and a judgment for the amount owed. The licensee demanded a jury trial on all issues. The district court denied the request for jury trial. The court viewed the entire action as equitable, the damages claim being merely incidental to the main claim. The Supreme Court reversed, pointing out that under Federal Rule 18, the parties must join the claims for money damages with the claim for equitable injunctive relief.27 Applying Beacon Theatres, the Court held that since the legal and equitable claims involved common factual issues, a jury must determine the legal claims before a final court determination of the equitable claims.28

Thus, Dairy Queen modified the test to determine whether a complaint joins separate claims for legal and equitable relief. The question is no longer whether prior to merger all claims would have been disposed of by a court of equity. Rather, the test is whether a party could bring any of the claims as actions at law. Moreover, even if the legal claim is incidental to the equitable claim, there is a right to a jury trial prior to court determination on the equitable issues.

Ross v. Bernhard 29 expanded Beacon Theatres and Dairy Queen by extending the seventh amendment guarantee to shareholder derivative suits. The plaintiffs, stockholders in a closed-end in-

25. Id. at 510 .

26. 369 U.S. 469 (1962).

27. Id. at 471 .

28. Justice Black, writing for the Court, made it plain that the decision in Beacon Theatres did not rest on the characterization of the complaint as primarily at law. He stated:

The holding in Beacon Theatres was that where both legal and equitable issues are presented in a single case, "only under the most imperative circumstances, circumstances which in view of the flexible procedures of the Federal Rules we cannot now anticipate, can the right to a jury trial of legal issues be lost through prior determination of equitable claims." That holding, of course, applies whether the trial judge chooses to characterize the legal issues presented as "incidental" to equitable issues or not.

Id. at 472-73 (citations omitted).

29. 396 U.S. 531 (1970). 
vestment company, sued on behalf of the corporation against the directors and investment brokers.

Until Ross, 30 the courts viewed the shareholder derivative action as a cause of action in equity, 31 excluded from the seventh amendment jury trial guarantee. Therefore, in order to hold that there was a right to jury trial, the Court departed from the purely historical test. 32

Justice White, writing for the majority, first set forth the holdings of Beacon Theatres and Dairy Queen. He then stated that the seventh amendment question depends on the nature of the issue to be tried rather than on the character of the overall action. ${ }^{33}$ The Court footnoted this last statement to aid in determining whether a particular issue is legal or equitable. The controversial footnote ten reads:

As our cases indicate, the "legal" nature of an issue is determined by considering, first, the pre-merger custom with reference to such questions; second, the remedy sought; and, third, the practical abilities and limitations of juries. Of these factors, the first, requiring extensive and possibly

30. The oniy exception was De Pinto v. Provident Security Life Ins. Co., 323 F.2d 826 (9th Cir. 1963), cert. denied, 376 U.S. 950 (1964). De Pinto is criticized in Note, The Right to a Jury Trial in a Stockholder's Derivative Action, 74 YALE L.J. 725 (1965).

31. See, e.g., Cohen v. Beneficial Loan Corp., 337 U.S. 541,548 (1949); Ross v. Bernhard, 403 F.2d 909, 912 (2d Cir. 1968), rev'd, 396 U.S. 531 (1970); Richland v. Crandall, 259 F. Supp. 274, 279 n.8 (S.D.N.Y. 1966); Liken v. Shaffer, 64 F. Supp. 432, 441 (N.D. Iowa 1946). The shareholder derivative suit did not exist in England in 1791 either at common law or in equity. Prunty, The Shareholder's Derivative Suit: Notes on Its Derivation, 32 N.Y.U. L. REv. 980, 980-85 (1957). When the action developed in England and the United States in the nineteenth century, it emerged as a wholly equitable action. Note, The Right to a Jury Trial in a Stockholder's Derivative Action, 74 YALE L.J. 725, 729-32 (1965).

32. The reason that under the prior practice a court of equity would dispose of the corporation's legal claim in a derivative suit was that irreparable injury was threatened because the corporation would not bring the action at law, and absent equitable determination of standing the stockholder could not. Noting that had courts of law recognized the right of the stockholder to bring such a suit the basis for equitable relief would have disappeared, Mr. Justice White indicated that the Rules had the same effect. By making it possible for a legal and an equitable claim to be brought as parts of the same action, they removed the barrier to a jury trial of the corporate claim after non-jury trial of the issue of standing. Since the case was thus to be treated as containing two claims, one equitable and one legal, the Seventh Amendment as interpreted in Beacon Theatres and Dairy Queen required that the legal claim go to the jury. 5 MOORE'S FEDERAL PRACTICE If 38.11, at 128.18 (2d ed. 1978). The result reached and the rationale employed in Ross are criticized in The Supreme Court, 1969 Term, 84 HaRv. L. REv. 1, 174-76 (1970); Note, Jury Trial in a Stockholder's Derivative Suit, 65 Nw. U.L. REv. 697, 700-07 (1970).

33. Ross v. Bernhard, 396 U.S. 531, 537-38 (1970). 
abstruse historical inquiry, is obviously the most difficult to apply. ${ }^{34}$

The Court cited no authority for this tripartite test. The first two criteria, namely, pre-merger custom and remedy sought, are similar to the historical test. However, traditionally, the relative abilities of judge and jury did not influence the characterization of a case as legal or equitable. 35 Thus, the third criterion created a

34. Id. at 538.

35. At no time in history was the line dividing equity from law-altogether-or even largely - the product of a rational choice between issues which were better suited to court or to jury trial. There is little to suggest that the chancellor's initial choice of a procedure borrowed from canon law reflected a considered rejection of jury trial. Rather, the choice between law and equity frequently was made upon consideration of other differences in the procedures of law and equity as they then stood.

F. JaMes \& G. HAZARD, Crvil Procedure 356-57 (2d ed. 1977). See also Redish, Seventh Amendment Right to Jury Trial: $A$ Study in the Irrationality of Rational Decision Making, 70 Nw. U.L. REv. 486, 523-24 (1975). The one exception involves an action for accounting, when the court will consider the practical limitations of juries. Historically, in equity, both concurrent and exclusive jurisdiction developed over matters of account. Concurrent jurisdiction existed even though claims were legal if the remedy at law was inadequate because of the complicated nature of the accounts. 5 MOORE's FEderal PRACTICE If 38.25, at 198-99 (2d ed. 1978). In Fowle v. Lawrason, 30 U.S. (5 Pet.) 495, 503 (1831), the Supreme Court stated:

In all cases in which an action of account would be the proper remedy at law, . . . the jurisdiction of a court of equity is undoubted. But in transactions not of this peculiar character, . . . great complexity at law should interpose, . . . in order to induce a court of chancery to exercise jurisdiction.

Thirty-six years later in Kirby v. Lake Shore \& Mich. S.R.R., 120 U.S. 130 (1887), the Court stated:

The case made by the plaintiff is clearly one of which a court of equity may take cognizance. The complicated nature of the accounts between the parties constitutes itself a sufficient ground for going into equity. It would have been difficult, if not impossible, for a jury to unravel the numerous transactions involved in the settlements between the parties, and reach a satisfactory conclusion as to the amount of drawbacks to which Alexander \& Co. were entitled on each settlement. Justice could not be done except by employing the methods of investigation peculiar to courts of equity.

Id. at 134 (citations omitted).

More recently, in Dairy Queen, Inc. v. Wood, 369 U.S. 469 (1962), the Supreme

Court recognized the court's discretion to try a case in equity when the accounts are extraordinarily complex:

The necessary prerequisite to the right to maintain a suit for an equitable accounting, like all other equitable remedies, is, as we pointed out in Beacon Theatres, the absence of an adequate remedy at law. Consequently, in order to maintain such a suit on a cause of action cognizable at law, as this one is, the plaintiff must be able to show that the "accounts between the parties" are of such a "complicated nature" that only a court of equity can satisfactorily unravel them. In view of the powers given to District Courts by Federal Rule of Civil Procedure 53(b) to appoint masters to assist the jury in those exceptional cases where the legal issues are too complicated for the jury adequately to handle alone, the burden of such a showing is considerably increased and it will indeed be a rare case in which it can be met.

Id. at 478 (citing Kirby v. Lake Shore \& Mich. S.R.R., 120 U.S. 130, 134 (1887)).

However, mere complication of facts is not a sufficient basis for equity jurisdiction. The facts and accounting must be so complex as to render the legal remedy inadequate. Curriden v. Middleton, 232 U.S. 633, 636 (1914); United States v. Bitter 
new factor in the determination of whether issues are legal or equitable.

Interestingly, the Court did not apply the third criterion in Ross. As a result, federal court judges were left without guidance in interpreting footnote ten. Based on the vagueness of the tripartite test, several commentators considered the third criterion a potential bombshell for limiting the right to jury trial.36 On the other hand, some commentators and judges suggested that the third criterion be ignored because of lack of clarity. ${ }^{37}$ Without

Root Dev. Co., 200 U.S. 451, 472-73 (1906); Kennedy v. Lakso Co., 414 F.2d 1249, 125354 (3d Cir. 1969).

36. Redish, Seventh Amendment Right to Jury Trial: A Study in the Irrationality of Rational Decision Making, 70 Nw. U.L. REv. 486, 523-24 (1975); Note, Ross v. Bernhard: The Uncertain Future of the Seventh Amendment, 81 YALE L.J. 112, 128 (1971). Ironically, the majority of articles and critical comments directed at the Ross decision focused on the great expansion of the right to jury trial because of Ross. Only in a few of the articles did the author raise the potential constriction of the right to jury trial through the three criteria in footnote 10. The majority of commentators either noted the footnote or disregarded it altogether. A sampling of the articles dealing with the trilogy of Beacon Theatres, Dairy Queen, and Ross includes: Redish, Seventh Amendment Right to Jury Trial: A Study in the Irrationality of Rational Decision Making, 70 Nw. U.L. REv. 486 (1975); Sower, "Complicated Issues" $v$. The Right to a Jury Trial: A Procedural Remnant in Kentucky Law Raises Constitutional Problems, 3 N. KY. ST. L.F. 173 (1975); Note, Congressional Provision for Nonjury Trial under the Seventh Amendment, 83 YALE L.J. 401 (1973); Note, Ross v. Bernhard: The Uncertain Future of the Seventh Amendment, 81 YALE L.J. 112 (1971); Comment, From Beacon Theatres to Dairy Queen to Ross: The Seventh Amendment, The Federal Rules, and a Receding Law-Equity Dichotomy, $48 \mathrm{~J}$. URB. L. 459 (1971). See also 5 Moore's Federal Practice If 38.11, at 128.6-.19, I 38.16, at 162.3-.9 (2d ed. 1978); C. Wright, Law of Federal CourTs, § 92, at 451-54 (3d ed. 1976).

37. Certain lower court cases seemed to disregard the footnote completely. See Crane Co. v. American Standard, Inc., 490 F.2d 332, 344 (2d Cir. 1973); Tights, Inc. v. Stanley, 441 F.2d 336, 340-42 (4th Cir. 1971). One court suggested that it is a questionable practice for the court to inquire into the practical limitations and abilities of juries in determining the existence of a right to jury trial. Ochoa v. American Oil Co., 338 F. Supp. 914, 922 (S.D. Tex. 1972). Judge Friendly dealt directly with the third prong of the Ross test in United States v. J.B. Williams Co., Inc., 498 F.2d 414 (2d Cir. 1974). He argued that

the footnote in Ross v. Bernhard was part of an argument for applying the Seventh Amendment right to a jury trial where it had not been recognized before the merger of law and equity-not a suggestion that a type of statute which had uniformly been held to carry the right of jury trial should now be construed to eliminate it.

Id. at 428. See also Sower, "Complicated Issues" v. The Right to a Jury Trial: A Procedural Remnant in Kentucky Law Raises Constitutional Problems, 3 N. KY. ST. L.F. 173, 190 (1975); 24 CASE W. RES. L. REv. 406, 415-16 (1973); Note, Monetary Claims Under Section 1983: The Right to Trial by Jury, 8 HARV. C.R.-C.L. L. REv. 613, 618-19 (1973); Note, Ross v. Bermhard: The Uncertain Future of the Seventh Amendment, 81 YALE L.J. 112, 129-33 (1971). 
guidance, the interpretation and the weight to be given the third criterion were left to the federal court judges.

The immediate effect of Ross was to expand the right to jury trial to shareholder derivative actions. However, several lower federal court judges have recently seized upon footnote ten in Ross to strike jury demands in complex cases. The remainder of this Comment will analyze these cases in detail and will discuss whether the current trend is consistent with Supreme Court theory.

The District Court Trend to Constrict the Right to JuRY TRIAL

Five recent corporate actions deal with the problem of a jury's ability to competently decide a complicated suit. In re Boise Cascade Securities Litigation, 38 In re United States Financial Securities Litigation, ${ }^{39}$ Bernstein v. Universal Pictures, Inc., ${ }^{40}$ and $I L C$ Peripherals Leasing Corp. v. International Business Machines, Inc. ${ }^{41}$ all sustained motions to strike jury demands based on the complexity of the facts and issues. However, Radial Lip Machine, Inc. $v$. International Carbide Corp. 42 refused to adopt the rationale of the other four cases, holding that complexity is not a basis for eroding the fundamental right to a jury trial. Each court based its holding on Ross, yet three schools of thought developed over the proper interpretation of footnote ten in Ross. This section will explore these five cases in detail.

In re Boise Cascade Securities Litigation 43 involved a claim for securities fraud against an acquiring company. The defendant moved to strike plaintiff's demand for a jury trial. Based on the complexity of the case, the district court held that the jury demand could be stricken without violating the seventh amendment.44 The facts of the case show why the court was so concerned about complex issues in a jury trial.

Boise Cascade Corporation acquired West Tacoma Newsprint Company in November, 1969. In 1971 and 1972, Boise Cascade wrote down the book value 45 of its assets, causing a drastic reduc-

38. 420 F. Supp. 99 (W.D. Wash. 1976).

39. 75 F.R.D. 702 (S.D. Cal. 1977).

40. 79 F.R.D. 59 (S.D.N.Y. 1978).

41. 458 F. Supp. 423 (N.D. Cal. 1978).

42. 76 F.R.D. 224 (N.D. III. 1977).

43. 420 F. Supp. 99 (W.D. Wash. 1976).

44. Id. at 105 .

45. See H. HenN, Law of Corporations $\$ 282$, at 560 (2d ed. 1970), for an explanation of book value and price manipulation. 
tion in the price of Boise Cascade shares.46 Former Newsprint shareholders alleged various violations of federal and state securities laws by Boise Cascade, the Boise Cascade accountant, directors, and officers.47 Other Newsprint shareholders filed similar actions after the original suit. 48

The Judicial Panel on Multidistrict Litigation 49 ordered the West Tacoma Newsprint Cases consolidated for pre-trial purposes with a case from the Eastern District of Missouri.50 The court appointed a Special Master to supervise discovery and denied motions by the defendants to sever the various cases for trial. At the time of the jury demand, counsel had already expended over 50,000 lawyer hours and had produced in excess of 900,000 documents. 51

The court held that a jury would not be a capable trier of fact because of the complexity of the factual issues and the time required to explore those issues.52 The court recognized that American jurisprudence favors jury trials in civil litigation. 53 However, the judge cited Ross for the proposition that the Supreme Court recognizes certain limits on the use of juries.54 The district court explicitly held that the third part of footnote ten in Ross has con-

46. Newsprint shareholder's value went from $\$ 75$ to $\$ 12$ per share. In re Boise Cascade Sec. Litigation, 420 F. Supp. 99, 101 (W.D. Wash. 1976).

47. Specifically, plaintiffs charged violations of $\$ \S 12(2)$ and $17(a)$ of the Securities Act of 1933, 15 U.S.C. $\$ \$ 77 l(2)$ and $77 \mathrm{q}(\mathrm{a})(1976) ; \S \S 10(\mathrm{~b})$ and $13(\mathrm{a})$ of the Securities Exchange Act of 1934 , 15 U.S.C. $\$ \S 78 \mathrm{j}(\mathrm{b})$ and $78 \mathrm{~m}$ (a) (1976); Rule 10b-5, 17 C.F.R. $\$ 240.10$ b-5 (1978); and WASH. REv. CODE ANN. \$§ 21.20.010 (1959), 21.20.430 (1974).

48. In re Boise Cascade Sec. Litigation, 420 F. Supp. 99, 101 (W.D. Wash. 1976).

49. See 28 U.S.C. $\$ 1407$ (1976) (creating the panel).

50. In re Boise Cascade Sec. Litigation, 420 F. Supp. 99, 101 (W.D. Wash. 1976).

51. Id.

52. Id. at 101-03. Each plaintiff had to prove individually a different measure of reliance. The case involved complicated usury laws and difficult and potential tax liabilities. Evidence of prior settlement actions brought by the State of California would be admitted to show the precise amount of the stock write-down. This evidence might raise the possibility of prejudice to the defendants. Finally, the case involved assets and liabilities in excess of one billion dollars over a period of more than five years.

53. There can be no doubt that jury trials are farored in civil litigation in this country. The combination of the Seventh Amendment and the merger of actions at law and equity into a single civil action under the Federal Rules of Civil Procedure encourages the use of juries to determine facts.

In re Boise Cascade Sec. Litigation, 420 F. Supp. 99, 103-04 (W.D. Wash. 1977) (citing Ross v. Bernhard, 396 U.S. 531, 539-40 (1970)).

54. Id. at 104. 
stitutional dimensions and is a limitation on or interpretation of the seventh amendment.55

According to Boise Cascade, the constitutional basis of footnote ten in Ross rests on the fifth and fourteenth amendments. Fairness must attend the resolution of civil actions. Central to fairness is a capable fact finder. At some point, the complexity of a case exceeds the jury's ability to decide the case in a capable manner. The question then arises whether an unqualified fact finder defeats fairness. 56

The court in Boise Cascade identified two factors dictating whether a jury should hear a case. First, the jury must represent a fair cross-section of the community.57 Because the Boise Cascade trial could last from four to six months, many employed persons would have been excused from jury service. The court suggested that the appearance of fairness is diminished, if not eliminated, when the jury in a commercial action contains jurors with no exposure to contemporary commercial or business environments. 58

The second factor is whether trial to the court would be superior to trial to a jury.59 The court in Boise Cascade found that a judge could use tools that would be unwieldy for a jury.60 The tools uniquely available to the judge include: review of daily transcripts, admission of depositions into evidence in place of reading relevant portions aloud, review of selected portions of testimony from the reporter's notes, and flexibility in scheduling trial activities. The court is able to study exhibits in depth and carry on colloquies with witnesses, expert and nonexpert alike, in an orderly and systematic manner. 61

The district court found that both factors were present. The court found that the jury would not represent a cross-section of the community. The tools available to the court made a trial to the judge superior to a jury trial. Based on these findings, Boise Cascade granted defendant's motion to strike jury demand.

In re United States Financial Securities Litigation ${ }^{62}$ exemplifies a "complex case."63 The case involved primarily federal securities law violations, California securities law violations, and common

55. Id. at 105 .

56. Id. at 104 .

57. Id.

58. Id.

59. Id.

60. Id. at 104-05. This inquiry can be criticized on the grounds that in almost every type of case, the "tools available to the court" will render any trial to the court superior to a trial by jury.

61. Id. at 104-05.

62. 75 F.R.D. 702 (S.D. Cal. 1977).

63. The first indicator of the extraordinary complexity of the case is the listing 
law fraud.64 The claims arose out of the bankruptcy of United States Financial.65 United States Financial's business consisted primarily of the construction and development of single-family residences throughout the United States. United States Financial's stocks and debentures were registered with the Securities Exchange Commission and traded on the New York Stock Exchange.

The underlying issues in the action included inaccuracies in financial statements, improper accounting standards, and inflation of income reported and filed by United States Financial. The depositions filled 150,000 pages. Over five million documents were available for discovery. The plaintiffs' Steering Committee identified nearly 12,000 documents the plaintiff intended to offer into evidence at trial. The court estimated a minimum of 100,000 pages of documentary evidence at trial.66 The plaintiffs intended to call, in

of counsel prior to the opinion. The list includes at least 45 separate law firms participating in the lawsuit.

64. Plaintiffs also asserted violations of Ohio securities laws and certain other common law claims. In addition to substantive claims, the complaints included allegations of vicarious liability, such as conspiracy, aiding and abetting, and the controlling person doctrine. At the time of the jury trial motion, the total number of United States Financial cases (including a SEC case) was 18 and the number of certified classes was five. As stated in the case:

More specifically, the $\mathbf{2 0}$ or so individual defendants and the 80 -odd corporate or partnership defendants are accused of eleven different violations of Section 10(b), five violations of Section 13(a), and violations of other sections of the Securities Exchange Act of 1934. The defendants are also said to have violated Sections $11,12(2)$ and 17 of the Securities Act of 1933 . In addition, common law counts based on negligence, gross negligence, and malpractice are found in many of the complaints .... Furthermore, the number of parties asserting claims against the defendants is not limited to the plaintiffs and the five certified classes. Many of the defendants have filed cross-claims against one another.

In re United States Fin. Sec. Litigation, 75 F.R.D. 702, 706 (S.D. Cal. 1977).

65. Various plaintiffs filed 10 lawsuits in the Southern District of California and in four other judicial districts relating to United States Financial's collapse. In 1974, the Judicial Panel for Multi-District Litigation ordered all these cases transferred to the Southern District for coordinated or consolidated pre-trial proceedings. See In re United States Fin. Sec. Litigation, 375 F. Supp. 1403 (J.P.M.D.L. 1974).

66. Judge Turrentine graphically explained the breadth of the documentary evidence:

The time and effort necessary to read and understand 100,000 pages comes a little into focus when one realizes that such a quantity of paper forms a stack over forty feet high (as high as a three-story building). In the alternative, one could say that such a quantity of paper would completely fill five large filing cabinets. Or, from a lawyer's perspective, reading those 100,000 pieces of paper would be like sitting down to read the first 90 volumes of the Federal Reporter, 2nd Series-including all the headnotes. 
person or by deposition, at least 241 witnesses. The court estimated a trial length of at least two years. ${ }^{67}$

In striking the jury demand, the court pointed out that the United States Supreme Court recognizes the power of the district court to try complex cases in equity and dispense with a jury trial.68 The court in United States Financial acknowledged that prior decisions allowing equity jurisdiction of complex issues involved the determination on the issue of damages as distinguished from the issue of liability. ${ }^{69}$ The court pointed out that Tights, Inc. v. Stanley ${ }^{70}$ distinguished complicated issues of liability from complicated issues of damages. Tights recognized that complex issues might arise during the liability portion of the trial. United States Financial noted that in Tights, the court reserved to the United States Supreme Court the question of extending eq-

In re United States Fin. Sec. Litigation, 75 F.R.D. 702, 707 (S.D. Cal. 1977).

67. Id. at 708 .

68. Id. at 709 (citing Kirby v. Lake Shore \& Mich. S.R.R., 120 U.S. 130, 134 (1887). See note 35 supra. See also F. Kirkham, Complex Civil Litigation-Have Good Intentions Gone Awry? (Apr. 1976) (address delivered at The Pound Conference), reprinted in 70 F.R.D. 199, 209 (1976).

69. 75 F.R.D. 702,710 (S.D. Cal. 1977). Prior to the five recent cases currently under discussion, the rule in Kirby v. Lake Shore \& Mich. S.R.R., 120 U.S. 130 (1887), see note 35 supra, has rarely been implemented. Recent applications are unclear whether equity accounting jurisdiction applies only to issues of damages or also to issues of liability. Two cases recognizing equity jurisdiction over accounts never addressed the question whether equity jurisdiction is limited to damages issues. See Goffe \& Clarkener, Inc. v. Lyons Milling Co., 26 F.2d 801 (D. Kan. 1928), affd, 46 F.2d 241 (10th Cir. 1931); Ochoa v. American Oil Co., 338 F. Supp. 914 (S.D. Tex. 1972). However, in Tights, Inc. v. Stanley, 441 F.2d 336 (4th Cir. 1971), the court explicitly held that equity accounting jurisdiction extends only to issues of damages:

However, the Supreme Court has specifically rejected the argument that equity jurisdiction may be invoked because of the complexity and diffculty of issues of liability as distinguished from the complexity of accounting damages.

...

If the scope of "equitable accounting" is to be expanded to encompass cases felt to be too complex or esoteric for trial to a jury, we think that expansion must come from the Supreme Court. We do not construe any language in the Dairy Queen opinion to sanction this further limitation of the right to jury trial.

Id. at $340-41$.

Furthermore, in Kennedy v. Lakso Co., 414 F.2d 1249 (3d Cir. 1969), the court stated:

While it is true that equity traditionally has had jurisdiction in actions for an accounting, it has always been recognized that there may be a suit for accounting at law and indeed the essential ingredient of equity's jurisdic. tion has been the complicated nature of the accounting. ... There is nothing on the present record to indicate that the accounting between the parties in the determination of profits or damages will be so complicated as to be beyond the power of a jury to determine.

Id. at 1253-54 (emphasis added). See also A.M.F. Tuboscope, Inc. v. Cunningham, 352 F.2d 150 (10th Cir. 1965); Swofford v. B \& W, Inc., 336 F.2d 406 (5th Cir. 1964).

70. 441 F.2d 336 (4th Cir. 1971). 
uity jurisdiction to liability issues. ${ }^{71}$ However, the United States Financial court extended equity jurisdiction over accounts to issues of liability, without precedent from the Supreme Court.72

The court supplies three general guidelines in determining whether a case is so complex that equity jurisdiction will attach and require a bench trial. ${ }^{73}$ First, even though they arise in the liability portion of a trial, complicated accounting problems are not generally amenable to jury resolution. However, as required by Dairy Queen, the issue is not subject to removal from the jury's province if a Special Master can meaningfully assist the jury. ${ }^{74}$ Second, the jury members must be capable of understanding and dealing rationally with the issues of the case. The final guideline is that an unusually long trial may make extraordinary demands upon a jury, making it difficult for jurors to function effectively throughout the trial.

Applying the three guidelines, the court found unequivocally that the jury was incompetent to try the case. The accounts were exceedingly complex. The law on liability included federal and state laws in addition to numerous legal theories. Moreover, the

71. 75 F.R.D. at 710. It is interesting to note that in Tights, the court never mentioned footnote 10 in Ross. Professor Redish suggests that perhaps the court failed to notice the footnote. Redish, Seventh Amendment Right to Jury Trial: A Study in the Irrationality of Rational Decision Making, 70 Nw. U.L. REv. 486, 524 n.148 (1975).

72. 75 F.R.D. at 710-11. The court cited two lower federal court decisions in support of the extension. In re Boise Cascade Sec. Litigation, 420 F. Supp. 99 (W.D. Wash. 1976); Ochoa v. American Oil Co., 338 F. Supp. 914 (S.D. Tex. 1972). The court in United States Financial claimed that Ochoa did not limit its reasoning to the damages portion of a trial. However, the language in Ochoa is dicta. Furthermore, in Ochoa, the court acknowledged that courts do inquire into the practical abilities and limitations of juries, yet questioned whether the inquiry is proper. Id. at 921-22. Moreover, United States Financial relied upon Boise Cascade which never addressed the issue of traditional equity jurisdiction over accounts. Boise Cascade is cited merely to point out that "at least" one court has decided that a case is so complex as to warrant striking jury demands. In re United States Fin. Sec. Litigation, 75 F.R.D. at 711. The court made no further attempt to thoroughly analyze the extension.

73. In re United States Fin. Sec. Litigation, 75 F.R.D. at 711.

74. FED. R. CrV. P. 53(b) and 53(e) set forth the function and qualifications of the Special Master. The Master aids the jury if the issues are so complex and complicated that laymen would have difficulty in making an adequate determination if unaided by an informal impartial expert. The Master is used merely as an expert witness who hears the evidence bearing on the complicated matters. The Master renders a report on the evidence to the jury. The report is subject to a ruling by the court upon any objections in point of law made at trial. The report is admissible as evidence of the matters found. See also 5A MoOre's Federal PracTICE If 53.14(2), at 3036 (2d ed. 1978). 
trial would be uncommonly long, and jury service of two years is beyond the jury's practical limitations.75 Finally, the court pointed out the waste of judicial time and unfairness to the plaintiffs if the court severed the individual actions and returned them to their respective districts for jury trials.

Bernstein v. Universal Pictures, Inc.76 involved an elaborate class action by lyricists and music composers alleging restraint of trade, copyright violations, monopolization, and antitrust violations by various entertainment distributors. 77 The court sua sponte raised the issue of jury competence to understand and render a fair decision in light of the complexity of the issues.

The court's analysis followed United States Financial in applying the three-pronged Ross test to extend traditional equity accounting jurisdiction. With respect to the pre-merger custom, the court accepted the consensus that private antitrust actions are legal. The relief sought included five equitable and two legal remedies. 78 Thus, the first two criteria favored a finding that the jury is the proper trier of fact. However, the court treated the third criterion of the practical abilities and limitations of the jury as dispositive, relying upon United States Financial and Boise Cascade. 79

The court compared the factual issues in Bernstein to the facts

75. In re United States Fin. Sec. Litigation, 75 F.R.D. at 714. The court did not include the Boise Cascade argument that a true cross-section of the community could not be represented on the jury.

76. 79 F.R.D. 59 (S.D.N.Y. 1978).

77. At the time of the motion, 65 named plaintiffs and 11 defendants remained in the action. Seven major law firms represented the parties. The size of the class constituted 400 to 900 members. Plaintiffs intended to call 15 witnesses and offer more than 550 exhibits. Defendants intended to call 100 witnesses and pre-marked 650 exhibits for introduction at trial. More than 70 depositions had been taken. The court estimated the minimum length of trial as to the plaintiffs alone at four months. Factually, the interrelationships between the parties were so varied and complex that almost no statement could be made about everyone similarly involved. Each class member had to prove his/her own injury and damages separately and each had to do so individually with respect to each contract made with each defendant. The court stated:

In addition, if, as appears likely, it is necessary to prove what percentage of the performance fees each named plaintiff would have received on each separate contract but for the conspiracy, plaintiffs will have to call each named plaintiff $(65)$, introduce each of the contracts $(1,050)$ by which they claim they were injured, and give proof on the 580 individual contract negotiations involved.

Id. at 63.

78. The defendants attempted to categorize the prayer for money damages as "equitable restitution." The court refused to accept this characterization stating:

[I] $t$ stretches the definition of equitable restitution and rejects established precedent unnecessarily to characterize as the prevention of "unjust enrichment" what is in reality an award of "damages to which plaintiff is legally entitled" if the allegations are upheld.

Id. at 67.

79. Id. at 69 . 
and issues that were found extraordinarily complex in United States Financial and Boise Cascade. The court first found that a trial of at least four months precluded empanelling a representative jury. ${ }^{80}$ Second, although antitrust suits are generally within the competence of juries, the complexity of the relationships between the parties in Bernstein rendered the action beyond the ability and competence of any jury to understand and decide. ${ }^{81}$ Third, severance of one defendant does not abate the complexity. Moreover, separate jury trials would probably result in separate and inconsistent verdicts, a severe injustice under the facts of the case.82 Finally, the special problems presented by the nature of the damages claimed, standing alone, would render the case unfit for jury determination.83

The court recognized two additional requirements. First, the Supreme Court requires something more than mere complexity to justify recourse to equity. The necessity for an accounting satisfies that requirement. ${ }^{84}$ The court found the requirement met in Bernstein without any explanation. Additionally, the possibility of referral to a Special Master must be rejected before a court can strike a jury demand on the basis of complexity. ${ }^{85}$ The court determined that even though a Special Master might aid in the accounting issue, the damages and liability issues were too complex for the jury. As a result, the court granted defendant's motion to strike jury demand.86

The plaintiffs in ILC Peripherals Leasing Corp. $v$. International Business Machines Corp. 87 (IBM) brought an action for monopolization of various markets in the computer industry. After a fivemonth jury trial ${ }^{88}$ and nineteen days of deadlocked deliberations,

80. Id. at 70 .

81. Id.

82. Id.

83. Id. at 71.

84. Id. at 70 (citing Goffe \& Clarkener, Inc. v. Lyons Milling Co., 26 F.2d 801, 804 (D. Kan. 1928), aff'd, 46 F.2d 241 (10th Cir. 1931)); In re United States Fin. Sec. Litigation, 75 F.R.D. 702 (S.D. Cal. 1977).

85. Bernstein v. Universal Pictures, Inc., 79 F.R.D. 59, 70 (S.D.N.Y. 1978).

86. The court stated that to hold that a jury trial is required would be to hold that the seventh amendment gives a single party at its choice the right to an irrational verdict. $I d$. at 71 .

87. 458 F. Supp. 423 (N.D. Cal. 1978).

88. Before jury selection, the defendant moved to strike plaintiff's jury demand on the ground the issues were too complex for a jury to decide fairly. The court denied the motion at that time. Because the action ended in a mistrial, the court felt the question deserved further consideration. 
the court declared a mistrial.89 The court granted IBM's motion for a directed verdict and made a separate ruling, striking the jury demand, in the event of a remand for trial.90

Resolution of the monopolization allegations required an understanding of a vast amount of advanced computer technology and sophisticated financial principles. 91 The case involved only a single defendant and a single plaintiff. However, the acts that plaintiff alleged as anti-competitive and predatory were extremely complex.92 In ruling on the jury demand, the court recognized that equity jurisdiction exists when the litigation is very complex.93 However, mere complication of facts alone is not a basis for equity jurisdiction. ${ }^{94} \mathrm{As}$ in Bernstein, the court stated that the first two Ross factors of pre-merger custom and remedy sought are traditionally regarded as legal in antitrust actions. Even so, the third factor of the practical abilities and limitations of jurors led the court to conclude that this case was equitable. The court found that the case involved more than complicated facts.95 The accounting and especially the engineering concepts were far beyond the experience and understanding of an ordinary jury. ${ }^{96}$

The court questioned whether the jury represented a true cross-section of the community. After excuses, only twenty-nine candidates remained from which fourteen jurors were to be selected. Only one juror had even limited technical education. The jurors probably represented a random cross-section of those who could afford to spend such an extended amount of time sitting on the jury.97

89. ILC Peripherals Leasing Corp. v. International Business Mach. Corp., 458 F. Supp. 423,426 (N.D. Cal. 1978).

90. Id. at 444.

91. The parties called 87 witnesses whose testimony filled more than 19,000 pages of transcript. More than 2,300 exhibits were admitted into evidence.

92. These included nondisclosure of interface information; unfair advantage with regard to IBM's fixed-term leasing plan; installation of a "disk drive" which assured use of IBM parts; new attachment strategies of disk drives to computer systems, communication control units, and central processing units. Each "act" also included allegations of unfair pricing.

93. ILC Peripherals Leasing Corp. v. International Business Mach. Corp., 458 F. Supp. 423, 446 (N.D. Cal. 1978) (citing Kirby v. Lake Shore \& Mich. S.R.R., 120 U.S. 130 (1887)). See note 35 supra.

94. ILC Peripherals Leasing Corp. v. International Business Mach. Corp., 458 F. Supp. 423, 446 (N.D. Cal. 1978) (citing United States v. Bitter Root Dev. Co., 200 U.S. 451 (1906)); Curriden v. Middleton, 232 U.S. 633 (1914). See note 35 supra.

95. ILC Peripherals Leasing Corp. v. International Business Mach. Corp., 458 F. Supp. 423, 446 (N.D. Cal. 1978).

96. $I d$.

97. The case was submitted to 11 jurors. The six men and five women on the jury ranged in age from 32 years to 65 years, with the majority over 50 . Several of the jurors were housewives. Those employed worked at jobs where they could be replaced, but where neither their jobs nor their incomes were in jeopardy. The 
Further, the court pointed out that the posture of the case posed a different problem from that confronting the court in Boise Cascade, United States Financial, or Bernstein. In those cases, each court's decision to strike the jury was based on experience as a trial court in evaluating the complexity of the case. Even so, the conclusion of jury incompetence was somewhat speculative. 98 However, in ILC Peripherals, the court based the decision to strike the jury on observations during the five-month trial. The jurors were diligent and conscientious, but their past experience did not prepare them to decide a case involving technical questions. 99 The fact that the first jury trial ended in a mistrial was an

court stated that it was understandable that people with such backgrounds would have trouble applying concepts like cross-elasticity of supply and demand, market share and market power, reverse engineering, product interface manipulation, exclusionary leasing, entrepreneurial subsidiaries, subordinated debentures, stock options, and modeling. Id. at 448.

98. Empirical data on jury performance is sparse. However, one major study of the American jury system does exist. H. KaLven \& H. ZEISEL, The AMERICAN JURY (1966). It is interesting that none of the courts dealing with jury competence cited the Kalven and Zeisel study. The authors state that most of the unrest over the jury today is limited to civil trials by jury. The implicit assumption is that jury determinations will be different from judge determinations in the same case. Id. at 9.

The study deals mainly with criminal trial juries. However, with respect to civil juries, the authors found that the jury and judge were in agreement $78 \%$ of the time. The agreement is roughly the same whether the trial is criminal or civil. Id. at 64 .

The study presents the judge-jury disagreement figures for the easy and the difficult cases. The hypothesis is that if the jury had any propensity to misunderstand the case, it would be more likely to disagree with the judge. Id. at 157. The result refuted the hypothesis that the jury does not understand. There was virtually no difference between the frequency of disagreement whether the case was easy or difficult. Id. (This part of the study was based on criminal trials.)

The conclusion drawn from the Kalven and Zeisel study is that much more em. pirical research is necessary to determine whether trial to a judge is superior to jury trial in complex civil litigation. The courts striking jury demands do not base jury incompetence upon empirical data. Rather, the judges base the decision simply upon their experience gained from the bench. The study tends to show that the claim that a jury will decide differently from the judge is without support. More research is necessary before judges can validly claim that issues are too complex for jury determination.

99. When asked by the court whether a case of this type should be tried to a jury, the foreman of the jury said, "If you can find a jury that's both a computer technician, a lawyer, an economist, knows all about that stuff, yes, I think you could have a qualified jury, but we don't know anything about that." Several of the other jurors indicated that they thought that the major stumbling block was the requirement that the verdict be unanimous. When they were questioned after the trial, most of the jurors indicated that they thought a complex antitrust case like this one should be tried to the court. 
important factor in striking the jury demand in ILC Peripherals. The court stated that perhaps jury trials should not be eliminated completely in complex antitrust litigation. However, if the first trial results in a mistrial, the system and the parties are better served by a trial to the court. 100 The curtailment of the right to a jury trial must be scrutinized with utmost care.101 However, the court held that the magnitude and complexity of the issues rendered the issues beyond the ability of any jury to understand and decide rationally. 102

The identical question of the right to a jury trial in complex litigation arose in Radial Lip Machine, Inc. v. International Carbide Corp. 103 However, the court reached the opposite conclusion in Radial Lip and severely criticized Boise Cascade.

Radial Lip involved an action for patent and trademark infringement and breach of contract. The defendant counterclaimed for declaratory relief and moved for a jury trial. Plaintiff moved to strike the defendant's jury demand. The parties included three corporations involved in the development and marketing of a "radial lip" drill, used in the metal cutting industry. The factual background revealed a series of corporate transactions transferring patent rights and creating numerous contractual obligations between the parties. Radial Lip ultimately filed a complaint alleging that the defendants violated federal trademark and patent laws, engaged in unfair competition, and violated certain Illinois statutes. 104 Radial Lip sought an injunction, an accounting, and damages. The defendants counterclaimed, requesting declaratory and equitable relief and damages.105

In the motion to strike jury demand, plaintiff argued that because of the complexity of the case, a bench trial would be fairer and more expeditious than a jury trial. Plaintiff relied on footnote ten in Ross and urged the court to adopt Boise Cascade.106 The court refused to adopt the plaintiff's position.

The Radial Lip court saw two possible interpretations of footnote ten. First, the Supreme Court in Ross may have intended

IIC Peripherals Leasing Corp. v. International Business Mach. Corp., 458 F. Supp. 423, 447-48 (N.D. Cal. 1978).

100. Id. at 448 .

101. Id. at 445 .

102. Id. ILC Peripherals never addressed the issue of whether equity accounting jurisdiction extends to liability issues. The court bypassed the question by following the basic rationale of United States Financial.

103. 76 F.R.D. 224 (N.D. Ill. 1977).

104. Id. at 225 .

105. Id.

106. Plaintiff claimed that footnote 10 in Ross is of constitutional dimension and is a limitation on or interpretation of the seventh amendment. 
that federal courts inquire into jury competence only as part of the threshold determination of whether an issue is legal or equitable in nature. Once the Ross three-pronged analysis characterizes an issue as legal, all future cases with the same issue trigger the same result.107

A second interpretation is that the practical limitations of juries operate as a general exception to the seventh amendment. Jury competence is an open question in every lawsuit and depends on the complexity of the specific problems presented rather than on the general nature of the legal issues involved.108 Radial Lip refused to accept the second interpretation. The court held that footnote ten contemplates a general analysis of the problems typically presented by a claim, not a case-by-case analysis of the complexity of the litigation. 109

The court also disagreed with Boise Cascade over another issue. In Radial Lip, the plaintiff argued for the application of footnote ten in respect to complexity of issues. The plaintiff urged that in an extraordinary case the complexity of the issues may be so great that only a court of equity can unravel the issues.110 The court in Radial Lip acknowledged that the Supreme Court in Dairy Queen recognized the exception of equity accounting jurisdiction; however, the court maintained that the exception is a nar-

107. Radial Lip Mach., Inc. v. International Carbide Corp., 76 F.R.D. 224, 227 (N.D. Ill. 1977).

108. Id.

109. We cannot read the Ross and Boise decisions as creating such a broad exception to the Seventh Amendment. We believe, in accordance with the first interpretation of Ross described above, that federal courts should only inquire into the competence of juries to decide "legal" issues when they initially examine the nature of the issues raised by a claim. The three Ross criteria are guides for determining whether a claim typically has a sufficient quantum of legal elements so that it must be tried to a jury .... The portion of the Ross test which weighs the practical abilities and limitations of juries contemplates a general analysis of the problems typically presented by those claims, not a specific case-by-case analysis of the complexity of the litigation. Otherwise, the courts would be forced to apply an unmanageable standard of complexity in every case before them. The likely result would be a dilution of the right to jury trial. Id. at 227-28.

It is ironic that Ross may now stand for the dilution of the right to jury trial when many early critics perceived it as expanding the right without limits. See note 36 supra.

110. Radial Lip Mach., Inc. v. International Carbide Corp., 76 F.R.D. 224, 228 (N.D. Ill. 1977). See note 35 supra. 
row one.111 Radial Lip interpreted Dairy Queen to allow equity jurisdiction as to damages if the issues are extraordinarily complex, but not as to liability. 112

Therefore, Radial Lip interprets Ross as requiring a two-tier analysis. First, the court uses footnote ten to make an initial determination of whether an issue is legal or equitable. Second, if the issue is legal, the court may apply traditional equity accounting jurisdiction as to the damages issues. However, Dairy Queen requires an exceptional showing of complexity to warrant equity jurisdiction over even the damages issues. Based on this analysis, the court held that the plaintiff failed to identify any complex accounting issues to justify equity jurisdiction. Plaintiff analyzed only the factual and liability issues presented and failed to make the exceptional showing required by Dairy Queen. As a result, the court denied the motion to strike jury demand.113

\section{ANALYSIS}

Three schools of thought have developed over the proper interpretation of footnote ten in Ross. Boise Cascade maintains that the third part of footnote ten has constitutional dimensions. The Boise Cascade court sees the third criterion as a limit to the seventh amendment right to jury trial. United States Financial, ILC Peripherals, and Bernstein do not go quite so far. These courts contend that footnote ten intended to reemphasize the practical abilities and limitations of the jury in any case involving complex facts and issues. Finally, Radial Lip contends that Ross aids only in the initial determination of whether an issue is legal or equitable. The three Ross factors determine the susceptibility of a claim to a trial by jury. If the action involves legal issues, the court may again look at the complexity and decide whether the accounting for damages is too complex for a jury to unravel. $R a$ dial Lip uses a two-tier analysis in contrast to the other cases which combine the two steps into one inquiry.

The difference of opinion in the decisions is twofold. First, the courts disagree whether equity accounting jurisdiction is limited

111. Radical Lip Mach., Inc. v. International Carbide Corp., 76 F.R.D. 224, 228 (N.D. Ill. 1977). See note 35 supra.

112. Radical Iip Mach., Inc. v. International Carbide Corp., 76 F.R.D. 224, 228 (N.D. Ill. 1977). See note 69 supra.

113. In addition, the court found that even if equitable accounting could be justified by the complexity of liability issues alone, this case did not surpass the limits of jury competence. For example, the case involved only two competing corporations, the parties estimated a trial length of only three weeks, the number of documents was not large, and the validity of the radial lip patent was undisputed. Thus, the court would uphold the demand even if based on the Boise Cas. cade criteria and rationale. 
to damages issues or includes liability issues. Second, the courts disagree whether footnote ten applies in determining complexity with regard to equity accounting jurisdiction or only to the initial determination whether an issue is legal or equitable.

The split of opinion whether equity jurisdiction attaches to liability issues as well as damages issues looms large. The four decisions striking jury demand either gloss over or deal unsatisfactorily with the traditional equity accounting jurisdiction issue. Even so, the courts hold that complexity of liability issues warrants equity jurisdiction and denial of jury trial. The courts seize upon the third criterion in footnote ten to bolster the equity jurisdiction contention. However, the courts have combined two separate doctrines into one, thereby confusing each doctrine.

Even if equity accounting jurisdiction includes liability issues, the courts still disagree whether the Supreme Court intended footnote ten to apply in determining equity accounting jurisdiction. Most of the lower court cases applying the Ross footnote do not involve complex business litigation.114 As a result, the third criterion of practical abilities and limitations of the jury is not as important a consideration as in the five commercial suits. The question of equity accounting jurisdiction based on complexity never arises. Yet, the courts still apply footnote ten in deciding the initial question of whether an issue is legal or equitable in nature. Therefore, many of the courts follow the Radial Lip analysis that footnote ten applies only to the initial determination rather than to the determination of equity accounting jurisdiction.115 The courts inquire in general whether a jury could competently understand that particular issue.

Minnis $v$. International Union, UAW116 applied the Ross test in an action by an employee against the union for failure to provide fair representation. The Minnis court found that the pre-merger custom and remedy sought pointed to legal jurisdiction. Then the court found that, in general, juries are suitable for deciding the exact issue presented. A properly instructed jury could adequately perform its duty of finding facts and making a damages

114. See, e.g., Minnis v. International Union, UAW, 531 F.2d 850 (8th Cir. 1975); United States v. J.B. Williams Co., Inc., 498 F.2d 414 (2d Cir. 1974); Farmers-Peoples Bank v. United States, 477 F.2d 752 (6th Cir. 1973); Dawson v. Contractors Transp. Corp., 467 F.2d 727 (D.C. Cir. 1972); Cleverly v. Western Elec. Co., 69 F.R.D. 348 (W.D. Mo. 1975).

115. See cases cited note 114 supra.

116. 531 F.2d 850 (8th Cir. 1975). 
award in an action for failure to provide fair representation.117

Another case following Radial Lip is Cleverly $v$. Western Electric Co.,118 an action under the Age Discrimination in Employment Act (ADEA). The complaint prayed for reinstatement, attorneys' fees and costs, back pay, and liquidated damages. The court first held that reinstatement and attorneys' fees and costs are clearly equitable. Next, the court separately analyzed the issues of back pay and liquidated damages as required by Ross. ${ }^{110}$ With respect to both issues, the court found the computations of damages well within the practical abilities of a jury. 120

In Dawson v. Contractors Transport Corp.,121 the dissenting judge maintained that Ross did not intend to limit the right to jury trial. Rather, Ross intended to extend the right to a class of plaintiffs who prior to merger would not have had the right to a jury trial.122 Judge Friendly expressed a similar view in United States v. J.B. Williams Co., Inc. ${ }^{123}$ Judge Friendly claimed that footnote ten was part of an argument for applying the seventh amendment right to jury trial where it had not been recognized before merger. The Supreme Court did not intend to suggest that a type of statute which had uniformly been held to carry the right to jury trial should now be construed to eliminate that right.124

An interesting case upholding the right to jury trial is Jones $v$. Orenstein. 125 Jones involved securities violations and at first glance appears to rely upon the Boise Cascade analysis. However, upon closer scrutiny, it becomes apparent that the analysis is also similar to Radial Lip.

117. Id. at 852-53. See also Rowan v. Howard Sober, Inc., 384 F. Supp. 1121 (E.D. Mich. 1974). Rowan involved an action by union members against their employer for breach of a collective bargaining agreement and against the union for breach of duty to fairly represent union members. The court held that although the facts may have been somewhat complex, they were no more complicated than antitrust and shareholder derivative suits which have been found suitable for jury determination.

118. 69 F.R.D. 348 (W.D. Mo. 1975).

119. The court cited footnote 10 and stated: "Because the right to jury trial depends on the issues in controversy rather than on the character of the overall action as noted above, the conclusions reached with respect to the different claims for relief made may differ. Therefore, each claim will be considered independently." Id. at 350 (emphasis added). The italicized portion parallels the analysis employed in Radial Lip, in contrast to the Boise Cascade practice of looking at the overall complexity of the action.

120. Again, the court looked more to the general abilities of a jury than to the specific facts in the case which could be labeled complex. See also Farmers-Peoples Bank v. United States, 477 F.2d 752 (6th Cir. 1973); Fellows v. Medford Corp., 431 F. Supp. 199 (D. Ore. 1977).

121. 467 F.2d 727 (D.C. Cir. 1972) (Fahy, J., dissenting).

122. Id. at 736 .

123. 498 F.2d 414 (2d Cir. 1974).

124. Id. at 428.

125. 73 F.R.D. 604 (S.D.N.Y. 1977). 
The Jones court initially determined that federal antitrust provisions are legal in nature and that plaintiff had a right to a jury trial.126 The court then cited Ross as authority that the court in its discretion could quash plaintiff's jury demand on the basis of the limitations of a jury's practical abilities.127 The court compared the complex issues in Jones to those in Boise Cascade, concluding that a jury could competently decide the case.128

Thus, the decision in Jones consisted of a hybrid analysis. The court followed Radial Lip in making the initial determination that the issues are legal. Radial Lip maintains that after the initial determination, the court may look to complexity in deciding whether equity accounting jurisdiction exists with regard to damages issues. However, in Jones, the court looked at complexity but relied upon Boise Cascade rather than working through the law of equity accounting jurisdiction. In sum, the court used a two-tier analysis, yet followed neither Radial Lip nor Boise Cascade. ${ }^{129}$

A probing question at this juncture is: What guidance has the United States Supreme Court supplied since Ross with respect to the right to jury trial? Three Supreme Court decisions deal with the right to jury trial. However, only one decision directly addresses footnote ten in Ross. ${ }^{130}$ In Curtis $v$. Loether, 131 the issue

126. Id. at 606 .

127. Id.

128. Id. In Jones, the court estimated trial length at six to eight weeks as compared to four to six months in Boise Cascade. In addition, the documentary evidence was manageable and thus the special tools available to the court did not make trial to the judge superior to jury trial.

129. The conflicting analyses in Jones lend credence to the claim that courts cannot agree on how to interpret Ross.

130. Two of the decisions are not directly on point. The first, Atlas Roofing Co., Inc. v. Occupational Safety and Health Review Comm'n, 430 U.S. 442 (1977), involved a cause of action under OSHA. The Court held that the seventh amendment does not prevent Congress from assigning to an administrative agency the task of adjudicating violations of the Act. When Congress creates a "new statutory right," it can restrict the right to jury trial. Id. at 459-61. See also NLRB v. Jones \& Laughlin Steel Corp., 301 U.S. 1 (1937). Second, Lorillard v. Pons, 434 U.S. 575 (1978), addressed the issue of whether there is a right to jury trial in private civil actions for lost wages under ADEA. The Supreme Court never reached the constitutional question, holding that the statute on its face demonstrated the intent to grant such a right. (The circuit court opinion did directly deal with the constitutional issue. The court employed the Ross test stating that the computation of back wages is not beyond the practical capabilities of a jury. 549 F.2d 950, 954 (4th Cir. 1977)). Only Curtis v. Loether, 415 U.S. 189 (1974), directly addresses footnote 10 in Ross.

131. 415 U.S. 189 (1974). 
was whether section 812 of the Civil Rights Act132 or the seventh amendment required a jury trial upon demand in an action for damages and injunctive relief. The Court pointed out that neither the statute on its face nor the legislative history clearly indicated whether a jury trial was required. Therefore, the Court based its opinion on an analysis of the seventh amendment. The Court held that a damages action under section 812 is an action to enforce legal rights. ${ }^{133}$ The Court worked through the first two criteria in footnote ten. The cause of action is analogous to a number of tort actions recognized at common law. More importantly, the Court found that the remedy sought is the traditional form of relief offered in the courts of law.134 The Supreme Court upheld the right of jury trial without once mentioning the practical abilities and limitations of the jury. ${ }^{135}$

132. Section 812 of the Civil Rights Act of 1968, 42 U.S.C. $\S 3612$ (1976), authorizes private plaintiffs to bring civil actions to redress violations of Title VIII, the fair housing provisions of the Act.

133. Curtis v. Loether, 415 U.S. 189, 195 (1974) (citing Ross v. Bernhard and Dairy Queen, Inc. v. Wood).

134. Id. at 195-96.

135. The only possible reference to the third criterion is the Court's discussion of possible jury prejudice:

We recognize, too, the possibility that jury prejudice may deprive a victim of discrimination of the verdict to which he or she is entitled. Of course, the trial judge's power to direct a verdict, to grant judgment notwithstanding the verdict, or to grant a new trial provides substantial protection against this risk, and respondents' suggestion that jury trials will expose a broader segment of the populace to the example of the federal civil rights laws in operation has some force. More fundamentally, however, these considerations are insufficient to overcome the clear command of the Seventh Amendment.

Id. at 198.

Various lower court decisions attempt to interpret the Supreme Court's failure in Curtis to discuss the third criterion in footnote 10. The first, Barber v. Kimbrell's, Inc., 577 F.2d 216 (4th Cir. 1978), involved the Truth in Lending Act, 15 U.S.C. $\$ \S 1601-1691$ (1976). Barber interpreted the language in Curtis to suggest two tests in determining whether an action based on a federal statute entails a constitutional right to jury trial. First, are the rights and duties created by statute analogous to rights and duties historically comprehended by the common law? Second, are the remedies sought legal rather than equitable in nature? In a footnote, the district court stated that Ross suggested the third test of the practical abilities and limitations of juries; however, since the Court in Curtis did not reiterate the third test, the test's continued vitality is in doubt. Barber v. Kimbrell's, Inc., 577 F.2d 216, 225 n.25 (4th Cir. 1978).

Furthermore, Van Ermen v. Schmidt, 374 F. Supp. 1070 (W.D. Wis. 1974), also casts doubt upon the continued vitality of the third criterion in light of Curtis. Van Ermen interpreted Curtis as holding that the nature of the relief sought is the most important test. Id. at 1074. The consideration of jury prejudice in Curtis ap. peared to be directed to interpretation of Title VIII of the Civil Rights Act of 1964, not to jury limitations in the seventh amendment context. Id. at n.9. Van Ermen viewed the third Ross standard as a reaffirmation of the traditional common law 
The recent trend to emphasize the Ross footnote is misplaced for three reasons. First, the Ross Court never applied the third criterion to the facts of the case. A shareholder derivative suit based on alleged violations of the Investment Company Act of 1940136 inherently involves issues of some complexity. Yet the Court never addressed the issue of jury competency.137 Second, the Ross Court makes no inquiry into the traditional concurrent equity jurisdiction of accounts even though the plaintiffs requested that the defendants account for and pay the corporation for their profits, gains, and losses. This tends to support the claim that the Supreme Court did not intend to limit access to jury trials.138 Lastly, the most recent Supreme Court decision citing and applying footnote ten in Ross did not mention the practical abilities and limitations factor. ${ }^{139}$

If the Ross test and equity accounting jurisdiction are separated, major policy considerations militate against striking jury demands. One consideration is that juries traditionally have coped with complex cases in areas where the courts are currently striking demands. An example is patent litigation. The original patent act in 1790 required that juries assess the amount of damages. 140 It was not until 1819 that equitable relief became avail-

practice of equity taking jurisdiction where transactions between parties were too complex for jury determination. Id. at 1075. The issues presented in Van Ermen were no different from issues common to tort actions typically tried before a jury. The issues were much less complex than those in Ross, which did not even trigger discussion of jury abilities in the Supreme Court's decision. Therefore, without more guidance from the Supreme Court, the judge in Van Ermen refused to elevate risk of jury prejudice to a determinant of seventh amendment protection. Id. at $1075-76$.

136. 15 U.S.C. $\$ \S 80 \mathrm{a}-1$ to $80 \mathrm{~b}-21$ (1976).

137. This lends credence to Radial Lip's analysis in two respects. First, the court should look only generally to jury limitations in the initial inquiry and not as they relate specifically to the facts before the court. Second, the court did not intend to limit the use of juries through its opinion in Ross. Issues involved in shareholder derivative actions are suitable for jury determination, and therefore no further inquiry into jury limitations is necessary.

138. It is interesting to note that the Supreme Court never combined the discussion of Ross with a discussion of equity jurisdiction over accounts involving complex facts and issues.

139. Curtis v. Loether, 415 U.S. 189 (1974).

140. Act of April 10, 1790, ch. 7, $\$ 4,1$ Stat. 109. This statute was repealed and replaced by a new act in 1793 . The new law dropped the specific reference to jury trial, but provided that damages were to be recovered "in an action on the case," a common law remedy. Act of Feb. 21, 1793, ch. 11, §5, 1 Stat. 318. The specification of recovery by "action on the case" was retained until the Patent Act of 1952 sub- 
able.141 Jury trials in patent cases are rooted in history, and limiting the right to jury trial is a new development in the law.142

Another consideration is the split of authority over whether equity jurisdiction over accounts is limited to the damages issue as opposed to the liability issue. None of the courts striking the jury demand adequately analyzed the question. ${ }^{143}$ If, however, the Supreme Court held that equity jurisdiction over accounts did extend to both liability and damages issues, the conflict with Ross can be reconciled. The court would initially employ the Ross test to determine if the issue was equitable or legal, taking into consideration the limitations of juries in general to try the type of issue before the court. If the issue is legal, then the equity accounting analysis comes into play. However, courts must heed the admonitions in Beacon Theatres and Dairy Queen that only the rare case is complex enough to warrant equity jurisdiction.

A final policy consideration is the fact that judges must determine complexity on an ad hoc basis. None of the courts cited any empirical data supporting their claims of jury incompetence. The closest empirical data was the fact of the mistrial in ILC Peripherals. The court drew upon tangible evidence of jury incompetence rather than on intuitive feeling based on experience gained while on the bench. 144

\section{CONCLUSION}

The purpose of this Comment is not to debate the advisability of juries in complex civil litigation. The use of juries obviously delays the system and increases the possibility of waste because of mistrials. The current trend to limit the use of juries in complex litigation may be desirable and may in fact be necessary. However, the lower federal courts are achieving the limitation based on vague and tenuous theories. A split among the jurisdictions has resulted from differing interpretations of the same Supreme Court decision. Until the United States Supreme Court supplies guidance regarding the interpretation of footnote ten in

stituted the phrase "civil action" to reflect the merger of law and equity in the federal courts. 35 U.S.C. $\$ 281$ (1976).

141. See Act of Feb. 15, 1819, ch. 19, 3 Stat. 481 (codified at 35 U.S.C. § 283 (1976)).

142. See the historical discussion of trial by jury in patent actions in Tights, Inc. v. Stanley, 441 F.2d 336, 342-44 (4th Cir. 1971). A similar argument can be made with respect to the copyright issues in Bernstein.

143. Boise Cascade never dealt with equity accounting jurisdiction. United States Financial relied on the dicta in Ochoa v. American Oil Co., 338 F. Supp. 914 (S.D. Tex. 1972), and on Boise Cascade. Boise Cascade, Bernstein, and ILC Peripherals cite the same cases as Radial Lip and reach opposite conclusions.

144. See note 98 supra. 
Ross, the current split and the growing trend to limit jury trials will inevitably continue. Clarification of the proper weight to be given the criterion of the practical abilities and limitations of a jury is necessary. Furthermore, the Supreme Court must clarify the interplay between footnote ten in Ross and equity jurisdiction over accounts in complex cases. Finally, guidance is needed as to the scope of equity jurisdiction over issues of liability. Until then, practitioners will continue to file motions to strike jury trial. In the meantime, parties are being denied the fundamental right to a jury trial.

The seventh amendment to the Constitution guarantees the right to trial by jury in civil actions of a legal nature. The United States Supreme Court developed the historical test to assure the fundamental right to a jury trial in actions at law. However, the merger of law and equity caused the Supreme Court to reevaluate the purely historical test in light of the Federal Rules of Civil Procedure.

In Ross v. Bernhard, the Supreme Court expanded the right to jury trial in an action previously considered equitable in nature. The Court set forth a three-pronged test in footnote ten to aid in determining whether an issue is legal or equitable. Footnote ten in Ross was not intended to be a limitation on the right to a jury trial.

Furthermore, the third criterion of the practical limitations and abilities of the jury is not of constitutional dimensions. The only two Supreme Court decisions applying the footnote have not discussed the third standard. Moreover, in both Ross $v$. Bernhard and Curtis $v$. Loether the Court used the footnote to extend rather than to contract the right to jury trial.

Courts may inquire into the complexity of issues with respect to the traditional common law practice of equity taking jurisdiction over complicated accounts. However, at most, the third criterion reaffirmed traditional equity jurisdiction over accounts as explained in Dairy Queen, Inc. v. Wood. The traditional limitations of extreme complexity and resort to special masters still exist. Only rare cases fall into traditional equity jurisdiction over accounts. In addition, the Supreme Court has yet to declare whether equity accounting jurisdiction is limited to issues of damages or extends to issues of liability as well.

Radial Lip Machine, Inc. v. International Carbide Corp. stands 
alone in upholding the right to jury trial as a fundamental right not to be diluted by issues of complexity. However, the analysis in Radial Lip is consistent with Supreme Court theory. The other recent cases have struck jury demands in a manner unintended by the Supreme Court. Guidance from the Supreme Court is needed in order to ensure that the new trend of striking jury demands in complex cases will not lead to erosion of the right to jury trial in all civil actions.

Tina Marie Prvonka 